\section{Association of parents' nutritional status, and sociodemographic and dietary factors with overweight/obesity in schoolchildren 7 to 14 years old}

\author{
Associação entre estado nutricional dos pais, \\ variáveis sociodemográficas e dietéticas \\ e o sobrepeso/obesidade em \\ escolares de 7 a 14 anos
}

\author{
1 Universidade Federal \\ de Santa Catarina \\ Florianópolis, Brasil. \\ Correspondence \\ C. O. Bernardo \\ Universidade Federal de \\ Santa Catarina. \\ Campus Universitário \\ Trindade, Florianópolis, SC \\ 88040-900, Brasil. \\ carlabernardoo@gmail.com
}

\begin{abstract}
To assess the association of parents' nutritional status, and dietary and sociodemographic factors with overweight/obesity in schoolchildren in Florianópolis Island, Santa Catarina State, Brazil, this cross-sectional epidemiological study examined 2,826 schoolchildren 7 to 14 years old, classified according to body mass index curves for age and sex recommended by the International Obesity Task Force. Data were analyzed using Poisson regression. The final model showed overweight/ obesity in boys associated directly with father's educational level, mother's age, and parents' nutritional status, and inversely with mother's educational level, and number of daily meals. Among girls, it associated directly with parents' nutritional status and the schoolchildren's age, and inversely with consumption of risk foods. The variables that associated with overweight/ obesity differed between the sexes, except parents' nutritional status. Boys and girls with both parents overweight or obese were, respectively, $80 \%$ and $150 \%$ more likely to exhibit the same diagnosis, indicating the need for interventions that include the family environment.
\end{abstract}

Overweight; Obesity; Parent-Child Relations
Carla de Oliveira Bernardo 1

Francisco de Assis Guedes de Vasconcelos 1

\section{Introduction}

Obesity is a chronic, non-communicable disease of worldwide concern due to its rapidly increasing prevalence in both developed and developing countries 1,2 . The emergence of childhood and teenage obesity is even more worrying in that studies have shown significant likelihood of this disturbance lasting into adult life 3,4 , and being responsible for increasing morbid-mortality in the population, because of its association with chronic, non-communicable diseases such as type-2 diabetes, dyslipedemias and arterial hypertension 1,2 .

Wang et al. 5 studied overweight trends in children and teenagers from 6 to 18 years old, finding that in Brazil the prevalence of overweight had tripled from $4.1 \%$ to $13.9 \%$ between 1974 and 1997 . According to Brazilian Household Budget Survey (POF) by the official statistics agency (Instituto Brasileiro de Geografia e Estatística - IBGE), the prevalence of overweight including obesity rose from $16.7 \%$ to $20.5 \%$ among adolescents from 10 to 19 years old in the period 2002-2003 to 2008 20096 .

A study by Ricardo et al. 7, in 2007, in Santa Catarina State, southern Brazil, identified 15.4\% and $6 \%$ overweight and obesity, respectively. The study examined 140,878 schoolchildren 6 to 10 years old with a nutritional diagnosis classified by body mass index (BMI) for age and sex as proposed by Cole et al. 8 and recommended by the 
International Obesity Task Force (IOTF). A 2002 study, also using the IOTF criteria, in Florianópolis, capital city of Santa Catarina State, found prevalence of overweight including obesity of $22.1 \%$ in children 7 to 10 years old ${ }^{9}$.

Although the etiology of obesity is not completely clear, its genesis is known to involve many factors, comprising a complex set of biological, behavioral and environmental factors 10,11. Lifestyle, including diet, is known to be preponderant in the increasing prevalence of childhood and teenage overweight/obesity. The number of daily meals, skipping breakfast, low intake of fruits, vegetables and grains, and high intake of sweets and fried foods have shown an association with overweight/obesity in schoolchildren 12,13,14.

Studies are indicating a significant association between overweight/obesity and sociodemographic and biological variables, such as parents' schooling 15, family income 16, the schoolchildren's sex 17 and, most importantly, obesity in the parents $10,11,18$.

Sexual maturation in schoolchildren, understood as a process of individual development through a set of biological changes that lead to the whole organism to reach mature state 19 , is pointed to by some authors as a factor associated with overweight/obesity in schoolchildren 20,21. Studies indicate that in girls early sexual maturation is associated with higher prevalences of overweight/obesity, while in boys the findings are still divergent 20,21 .

Aware that there is currently worldwide interest in studying overweight/obesity in schoolchildren and the related factors, and given the large number of studies currently being conducted on the subject, the authors decided to conduct a differential study, important for investigating not only sociodemographic variables and parents' nutritional status, but also the schoolchildren's dietary behavior, and also considering the schoolchildren's sexual maturation in the adjusted models. Accordingly, this article aims to examine how parents' nutritional status, sociodemographic variables (sex, school type, and schoolchildren's age, parents' age bracket and schooling, and per capita monthly income), and dietary variables (number of daily meals, skipping breakfast, consumption of health-risk and health-protective foods) associate with overweight/obesity in 7 to 14 year old schoolchildren in the municipality of Florianópolis.

\section{Method}

\section{Study population, sample size and sampling}

This cross-sectional study was conducted in 2007 in the municipality of Florianópolis, in connection with a broader research project. The city has among the highest social and health indicators in Brazil, with infant mortality at 8 per 1000 live births and a Human Development Index of 0.875 , as compared with a national infant mortality rate of 19.5/1000 live births and HDI of 0.81322 .

The study used a probabilistic sample of the population of 7 to 14 year old school children enrolled in public and private schools in the municipality. According to City Health Department (Secretaria Municipal de Saúde - SMS) figures, in 2006, the school population in this age range in the municipality comprised 53,679 pupils (25,619 from 7-10 years old and 28,060 from 1114 years old).

The calculated sample size - considering $10 \%$ prevalence of obesity among children $7-10$ years old 23 and $17 \%$ among adolescents $11-14$ years old 24 , with a 2 percentage point margin of error and a sample design effect of 1.3 - numbered 2,800 schoolchildren (1,100 for the 7-10 year age group and 1,700 for the 11-14 year olds). Also considering $10 \%$ random loss, the final total was 3,100 schoolchildren from $7-14$ years old to be studied.

With this number of schoolchildren it would be possible, in testing the associations, to detect prevalence ratios (PRs) of 2.00 or less as statistically significant, always providing exposure prevalence was $10 \%$ or higher, for a $10 \%$ outcome prevalence, $5 \%$ alpha level, $80 \%$ power, $10 \%$ losses and $15 \%$ adjustment for confounders.

The study used a two-stage probabilistic sampling design. The first stage involved grouping the schools in the municipality of Florianópolis into four strata, by geographical area (center/ mainland or beaches) and by school type (public or private). Within each stratum, schools were selected at random. Of the total of 87 schools (33 private and 54 public), approximately $20 \%$ were selected (17 schools: 11 public and 6 private). At the second stage, from each school selected, $30 \%$ of the pupils were drawn at random to attain the required sample of 3,100 schoolchildren. For the analyses, the design effect and the sampling plan were used both for estimating prevalences and for analyzing the related factors.

All schoolchildren aged from 7 to 14 years, enrolled in public and private schools in Florianópolis and residing in the municipality were considered eligible. 


\section{Data collection and analysis}

The schoolchildren's anthropometric measurements were taken in 2007, according to a previously established protocol following World Health Organization (WHO) guidelines 25, which are based on recommendations by Lohman et al. 26. Body weight was measured using Marte electronic scales, model PP 180 (Marte Balanças e Aparelhos de Precisão Ltda., São Paulo, Brazil), with capacity of $180 \mathrm{~kg}$ and accurate to $100 \mathrm{~g}$, and height was measured using an Alturexata stadiometer (Alturexata Ltda., Belo Horizonte, Brazil), accurate to $1 \mathrm{~mm}$.

The team responsible for data collection comprised 10 previously trained examiners. Training was given at two points, in September 2006 and in March 2007, when intra-examiner and inter-examiner errors, respectively, were assessed. Theoretical and practical workshops on measurement technique were held on both occasions in order to standardize the anthropometric measurements. After the workshops, a pilot study involving anthropometric evaluations was run at two schools, one public and one private, in the municipality of Florianópolis, in order to gauge the technical measurement error, as published in a previous study 27 . Establishing the technical measurement error ensured the study's internal validity, minimizing the possibility of bias in the measurements.

The schoolchildren's nutritional diagnosis was established by way of sex- and age-matched BMI curves, as in Cole et al. ${ }^{8}$, as recommended by the IOTF. Against this benchmark, the specific cut-off points for classifying overweight and obesity in under 18 year olds were defined on the basis of the BMI points for adults (overweight: $\mathrm{BMI} \leq 25$ to $<30 \mathrm{~kg} / \mathrm{m}^{2}$ and obesity: $\geq 30 \mathrm{~kg} / \mathrm{m}^{2}$ ). For the analyses, the schoolchildren were classified into two groups: not overweight or obese (values equivalent to $\mathrm{BMI}<25 \mathrm{~kg} / \mathrm{m}^{2}$ in adults) and overweight or obese (values equivalent to $\mathrm{BMI} \geq 25 \mathrm{~kg} / \mathrm{m}^{2}$ in adults).

Identification data on the schoolchildren (name, date of birth, grade, and type of school) were obtained from lists supplied by the schools. These data were transferred to the schoolchildren's anthropometric form, which was filled in by the data collection team. For the analyses, the schools were categorized into public and private, and the schoolchildren's ages were also categorized dichotomously into 7-10 years and 11-14 years.

The schoolchildren's dietary data (number of daily meals, skipping breakfast, and consumption of health-protective and -risk foods) were obtained using version 3 of the previous-day food questionnaire (Questionário Alimentar do Dia Anterior - QUADA) 28, a structured, illustrated instrument for application in school-age children. This version of the QUADA presents six meals ordered chronologically (breakfast, morning snack, lunch, afternoon snack, dinner, and evening snack), each meal illustrated with 21 foods or food groups. The foods were selected considering not only the dietary patterns of children in the age group under observation, but the foods available, the menu offered at the public schools, and a food guide for Brazil's population (Guia Alimentar para a População Brasileira) 29.

The questionnaire was applied in a room prepared for that purpose, where it was explained to the schoolchildren how to complete the instrument. In order to present the questionnaire to the pupils, four posters were prepared, each showing two meals, identical to those on the questionnaire supplied to the children. After distributing the questionnaires, the researchers explained all the meals and foods illustrated, and the schoolchildren were then instructed to circle on their questionnaire what they had eaten at each meal on the previous day. In this process, for each meal represented on the poster, the researcher went through all the foods shown and the possible times that the meal might take place. The schoolchildren were instructed to leave blank the part of the form relating to any meal they had not eaten.

For purposes of analysis, the number of meals daily was divided into four categories: up to 3 meals; 4 meals; 5 meals; and 6 meals daily. Skipping breakfast was categorized into: Yes (if the schoolchildren omitted this meal, and consumed no food of any kind) and No (if the schoolchildren had this meal, and consumed at least one kind of food). In analyzing consumption of health-protective and health-risk foods, foods of the group of fruits, natural juices, leaf vegetables, other vegetables, and vegetable soup. Health-risk foods were those belonging to the group of chocolate products, soft drinks and artificial juices, sweets, packaged snacks, French fries and fastfood snacks. Consumption of health-protective foods was categorized as: appropriate ( $\geq 5$ times a day) and inappropriate ( $\leq 4$ times a day). Consumption of health-risk foods was classified as: appropriate (up to once a day) and inappropriate ( $\geq 2$ times a day), as recommended by the Guia Alimentar para a População Brasileira 29.

At the request of the participating schools, data on sexual maturation were collected from only the 11-14 year old schoolchildren. These data were obtained using the self-assessment technique 21 . After answering the dietary questionnaire, the schoolchildren were directed 
individually to a separate room, where they received the worksheets with drawings of the figures corresponding to the sexual maturation stages proposed by Tanner 19, and answered a questionnaire on their age at menarche/spermarche and about the stages of sexual maturation. The worksheets contained drawings showing the growth stages of pubic hair and breasts in girls, and pubic and genital hair in boys. The five growth stages were numbered from 1 to 5 , with one representing immaturity and 5, maximum maturity. For purposes of analysis, the schoolchildren's sexual maturity was classified in two ways: by age at menarche/spermarche, and by pubic hair and breast/genital development stages. The former was classified dichotomously: $\leq 11$ years and $\geq 12$ years. The latter was classified by pubic hair and breast/genital growth stage matching differences: matching stages (same stage for pubic hair and breast/genital development); pubic hair one or two stages ahead of breast/genital development; or pubic hair one or two stages behind breast/genital development. The two variables were used as covariables during statistical analysis for the 11 to 14 year old schoolchildren.

The self-reported data for weight, height, age, schooling and parents' monthly income-and the number of residents in the household, for subsequent calculation of per capita income - were taken from the sociodemographic and anthropometric questionnaire sent to the parents together with the declaration of free, informed consent. The parents' nutritional status was diagnosed by way of BMI, using WHO cut-offs: adults were considered underweight with $\mathrm{BMI}<18.5 \mathrm{~kg} / \mathrm{m}^{2}$; eutrophic with BMI $\geq 18.5$ and $<25 \mathrm{~kg} / \mathrm{m}^{2}$; overweight with $\mathrm{BMI} \geq 25$ and $<30 \mathrm{~kg} / \mathrm{m}^{2}$; and obese with $\mathrm{BMI} \geq 30 \mathrm{~kg} / \mathrm{m}^{2} 25$. For purposes of analysis, the parents were categorized into: neither parent overweight/obese; only father overweight/obese; only mother overweight/obese; or both parents overweight/obese. Age was categorized dichotomously: 20-39 years and $\geq 40$ years; schooling was divided into: 0-8 years schooling, 9-11 years schooling, and $\geq 12$ years schooling; and monthly per capita income was classified by terciles ( 1 st tercile: $\leq \mathrm{R} \$ 240.00 ; 2^{\text {nd }}$ tercile: $>\mathrm{R} \$ 240.00$ and $\leq \mathrm{R} \$ 500.00$; and 3rd tercile: $>\mathrm{R} \$ 500.00$ ).

All data collected were double-input into EpiData version 3.2 software (Epidata Assoc., Odense, Denmark) by previously trained data inputters. After verification of data consistency, the analyses were performed using the statistics program Stata version 11.0 (Stata Corp., College Station, USA). The analyses were corrected for design effect and study sampling plan by using the Stata svy command both for the overweight/ obesity prevalence estimates and for the association analyses.

Bivariate and multivariate analyses were conducted for boys and girls using Poisson regression 30 based on the analytical model shown in Table 1 . At level 1 were the demographic and socioeconomic variables for the parents and schoolchildren; at level 2, the parents' nutritional status and the type of school; and, at level 3, the behavioral data for the schoolchildren. The schoolchildren's sexual maturity was used as a covariable, because it associates with variables at different levels.

The analyses were stratified by sex, because the outcome prevalences differed between boys and girls. First of all, bivariate analysis was conducted to ascertain the associations between the dependent variable (prevalence of overweight/ obesity) and each independent variable, to derive the prevalence ratios and respective 95\% confidence intervals (95\%CI). Then multivariate analysis was conducted, adjusting among the variables at each level, and for those at the next highest level. The variables were selected using the backward method, and those with $\mathrm{p}$-values $\leq 0.20$ were retained. The statistically significant variables $(\mathrm{p} \leq 0.05)$ were retained in the final model. The results are shown as prevalence ratios and respective $95 \% \mathrm{CI}$.

The research protocol was approved by the ethics committee for research with human subjects of Santa Catarina Federal University (Universidade Federal de Santa Catarina; no. 028/2006). The schoolchildren's parents or guardians signed a declaration of free and informed consent.

\section{Results}

Data were obtained for 2863 (92.3\%) of the total of 3100 schoolchildren selected for the study. Of these, 37 schoolchildren were excluded for being over 7 or under 14 years old, leaving 2826 (91.2\%) schoolchildren participating, satisfying the calculated minimum sample size (2800 schoolchildren).

The overall prevalence of overweight/obesity among school children 7 to 14 years old in Florianópolis was $21.9 \%$, that is, $25.4 \%$ (95\%CI: 23.0-28.0) of boys and 18.7\% (95\%CI: 16.3-21.5) of girls, according to criteria recommended by the IOTF 8 . There was significant difference between the sexes $(p<0.001)$. The prevalence of overweight/obesity among fathers and mothers was $55.1 \%$ and $34.1 \%$, respectively.

In the sample distribution, shown in Table 2, the proportions of male and female schoolchildren were similar. Forty-four percent of the 
Analytical model indicating relationship between the independent variables investigated and the outcome. Florianópolis, Santa Catarina State, Brazil, 2007.

\begin{tabular}{|c|c|c|}
\hline Level & Variables & \\
\hline \multirow[t]{4}{*}{1} & Parents' age group & Schoolchildren's sexual maturity \\
\hline & Parents' schooling & \\
\hline & Per capita monthly income & \\
\hline & Schoolchildren's age groups & \\
\hline \multirow[t]{2}{*}{2} & Parents' nutritional state & \\
\hline & Public/private school & \\
\hline \multirow[t]{5}{*}{3} & Schoolchildren's dietary behavior: & \\
\hline & Consumption of protective foods & \\
\hline & Consumption of risk foods & \\
\hline & Skipping breakfast & \\
\hline & Number of meals daily & \\
\hline 4 & Prevalence of overweight/obesity among the schoolchildren & \\
\hline
\end{tabular}

schoolchildren were from 7 to 10 years old and $56 \%$, from 11 to 14 years old, and the great majority $(75 \%)$ were at public schools. As regards the fathers and mothers ages, $54 \%$ of the fathers were 40 years old or older, while most of the mother's (62\%) were from 20 to 39 years old. In terms of schooling, fathers and mothers displayed similar proportions of years of schooling. Regarding the parents' nutritional status, $31.7 \%$ of the schoolchildren had fathers and mothers with no overweight/obesity, $34.7 \%$ had only the father overweight/obese, $13.2 \%$ only the mother, and $20.4 \%$ had both parents overweight/obese. The dietary variables showed that $87.6 \%$ of the schoolchildren's consumption of health-protective foods was inappropriate (fewer than five times a day); $80.4 \%$ consumed health-risk foods twice or more times a day; $94.5 \%$ had breakfast; $23 \%$ ate up to 3 meals; $27.9 \%$ had 4 meals; $32 \%, 5$ meals; and $17.1 \%, 6$ meals daily.

The crude analyses and the analyses adjusted between the independent variables and overweight/obesity among the male schoolchildren are shown in Table 3. In the crude analysis, the prevalence of overweight/obesity was greater among boys whose mother and father were 40 years old or more, earned higher per capita income, whose parents had more schooling, and who went to private schools. The parents' nutritional status also associated with the outcome, with the hazard of overweight/obesity approximately $80 \%$ greater when both parents were overweight/obese than when neither parent was. When only the father was overweight/obese, the hazard was intermediate (PR $=1.48$; 95\%CI: 1.18 1.86), and when only the mother was overweight/ obese, the hazard was lower (PR $=1.23$; 95\%CI: 0.91-1.68). Of the dietary variables, only the number of meals daily associated with the outcome, with a larger number of meals displaying a protective effect on hazard of overweight/obesity.

At the first level of the adjusted analysis, the mother's age, the father's schooling, and the mother's schooling showed an association with the outcome. At the second level, the parents' nutritional status continued to show a strong association. Of the dietary variables, at the third level of the analytical model, the number of meals daily continue to be associated with overweight/ obesity in the schoolchildren (Table 4).

The crude and adjusted analyses of the independent variables and overweight/obesity in the girls are shown in Table 5. In the crude analysis, the prevalence of overweight/obesity was greater among girls 7 to 10 years old. The parents' nutritional status showed a strong association: overweight/obesity in both parents increased the hazard of overweight/obesity in the girls by almost $200 \%$ as compared with those neither of whose parents were overweight/obese. Of the di- 
Distribution of the sample investigated, by independent variables and sex. Florianópolis, Santa Catarina State, Brazil, 2007.

\begin{tabular}{|c|c|c|c|c|c|c|}
\hline \multirow[t]{2}{*}{ Variables } & \multicolumn{2}{|c|}{ Total } & \multicolumn{2}{|c|}{ Male } & \multicolumn{2}{|c|}{ Female } \\
\hline & $\mathrm{n}$ & $\%$ & $\mathrm{n}$ & $\%$ & $\mathrm{n}$ & $\%$ \\
\hline \multicolumn{7}{|l|}{ Level 1} \\
\hline \multicolumn{7}{|l|}{ Father's age group (years) * } \\
\hline $20-39$ & 1,187 & 46.3 & 586 & 47.6 & 601 & 45.2 \\
\hline$\geq 40$ & 1,375 & 53.7 & 645 & 52.4 & 730 & 54.8 \\
\hline \multicolumn{7}{|l|}{ Mother's age group (years) * } \\
\hline $20-39$ & 1,724 & 62.5 & 831 & 63.2 & 893 & 61.8 \\
\hline$\geq 40$ & 1,035 & 37.5 & 483 & 36.8 & 552 & 38.2 \\
\hline \multicolumn{7}{|l|}{ Father's schooling (years) * } \\
\hline $0-8$ & 890 & 35.1 & 417 & 34.0 & 473 & 36.1 \\
\hline $9-11$ & 820 & 32.3 & 409 & 33.4 & 411 & 31.4 \\
\hline$\geq 12$ & 826 & 32.6 & 400 & 32.6 & 426 & 32.5 \\
\hline \multicolumn{7}{|l|}{ Mother's schooling (years) * } \\
\hline $0-8$ & 962 & 35.2 & 464 & 35.5 & 498 & 35.0 \\
\hline $9-11$ & 944 & 34.6 & 457 & 35.0 & 487 & 34.2 \\
\hline$\geq 12$ & 825 & 30.2 & 386 & 29.5 & 439 & 30.8 \\
\hline \multicolumn{7}{|l|}{ Per capita monthly income $(\mathrm{R} \$)$ * } \\
\hline 1st tercile $(\leq 240.00)$ & 833 & 34.5 & 401 & 35.0 & 432 & 34.1 \\
\hline $2^{\text {nd }}$ tercile ( $>240.00$ and $\left.\leq 500.00\right)$ & 893 & 37.0 & 430 & 37.5 & 463 & 36.5 \\
\hline 3rd tercile (> 500.00) & 689 & 28.5 & 316 & 27.5 & 373 & 29.4 \\
\hline \multicolumn{7}{|l|}{ Schoolchild's age group (years) } \\
\hline $7-10$ & 1,231 & 43.6 & 602 & 44.4 & 624 & 42.5 \\
\hline $11-14$ & 1,595 & 56.4 & 755 & 55.6 & 845 & 57.5 \\
\hline \multicolumn{7}{|l|}{ Level 2} \\
\hline \multicolumn{7}{|l|}{ School type } \\
\hline Public & 2,131 & 75.4 & 1,021 & 75.2 & 1,110 & 75.6 \\
\hline Private & 695 & 24.6 & 336 & 24.8 & 359 & 24.4 \\
\hline \multicolumn{7}{|l|}{ Parents' nutritional state * } \\
\hline Neither overweight/obese & 741 & 31.7 & 346 & 30.9 & 395 & 32.5 \\
\hline Father overweight/obese & 809 & 34.7 & 401 & 35.8 & 408 & 33.6 \\
\hline Mother overweight/obese & 308 & 13.2 & 149 & 13.3 & 159 & 13.1 \\
\hline Both overweight/obese & 477 & 20.4 & 225 & 20.0 & 252 & 20.8 \\
\hline \multicolumn{7}{|l|}{ Level 3} \\
\hline \multicolumn{7}{|l|}{ Consumption of protective foods ** } \\
\hline Appropriate ( $\geq 5$ times/day) & 350 & 12.4 & 162 & 12.0 & 188 & 12.7 \\
\hline Inappropriate (< 5 times/day) & 2,476 & 87.6 & 1195 & 88.0 & 1,281 & 87.3 \\
\hline \multicolumn{7}{|l|}{ 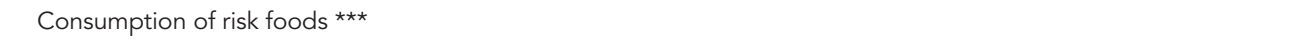 } \\
\hline Appropriate (<2 times/day) & 554 & 19.6 & 259 & 19.1 & 296 & 20.1 \\
\hline Inappropriate ( $\geq 2$ times/day) & 2,272 & 80.4 & 1,098 & 80.9 & 1,173 & 79.9 \\
\hline \multicolumn{7}{|l|}{ Skip breakfast } \\
\hline No & 2,666 & 94.3 & 1,291 & 95.1 & 1,375 & 93.6 \\
\hline Yes & 160 & 5.7 & 66 & 4.9 & 94 & 6.4 \\
\hline \multicolumn{7}{|l|}{ Number of meals/day } \\
\hline Up to 3 & 650 & 23.0 & 298 & 22.0 & 352 & 23.9 \\
\hline 4 & 790 & 27.9 & 360 & 26.5 & 430 & 29.3 \\
\hline 5 & 904 & 32.0 & 454 & 33.5 & 450 & 30.7 \\
\hline 6 & 482 & 17.1 & 245 & 18.0 & 237 & 16.1 \\
\hline Total & 2,826 & 100.0 & 1,357 & 48.0 & 1,469 & 52.0 \\
\hline
\end{tabular}

* The total does not correspond to 2,826 because of data not completed on the parents' sociodemographic and anthropometric questionnaires;

** Fruit, natural juices, leaf vegetables, other vegetables, vegetable soup;

*** Chocolate products, soft drinks, artificial juices, sweets, packaged snacks, French fries and fast-food. 
Prevalence and crude and adjusted prevalence ratios for overweight/obesity in male schoolchildren, by independent variables. Florianópolis, Santa Catarina State, Brazil, 2007.

\begin{tabular}{|c|c|c|c|c|}
\hline Variables & $\mathrm{n}$ & $\begin{array}{c}\text { Overweight/Obesity } \\
\%(95 \% \mathrm{Cl})\end{array}$ & Crude PR $(95 \% \mathrm{Cl})$ & Adjusted PR (95\%Cl) \\
\hline \multicolumn{5}{|l|}{ Level 1} \\
\hline Father's age group (years) * & & & $p=0.011$ & $p=0.202$ \\
\hline $20-39$ & 586 & $21.7(18.2-25.6)$ & 1.00 & 1.00 \\
\hline$\geq 40$ & 645 & $29.0(25.3-32.9)$ & $1.33(1.07-1.64)$ & $1.25(0.88-1.78)$ \\
\hline Mother's age group (years) * & & & $p=0.009$ & $p=0.004$ \\
\hline $20-39$ & 831 & $23.2(20.9-25.7)$ & 1.00 & 1.00 \\
\hline$\geq 40$ & 483 & $28.8(24.9-32.9)$ & $1.23(1.06-1.42)$ & $1.40(1.12-1.74)$ \\
\hline Father's schooling (years) * & & & $p=0.005 *$ & $p=0.009$ * \\
\hline $0-8$ & 417 & $22.3(19.4-25.5)$ & 1.00 & 1.00 \\
\hline $9-11$ & 409 & $24.9(20.5-30.0)$ & $1.11(0.87-1.41)$ & $1.09(0.83-1.42)$ \\
\hline$\geq 12$ & 400 & $29.0(25.7-32.5)$ & $1.29(1.09-1.53)$ & $1.51(1.17-1.95)$ \\
\hline Mother's schooling (years) * & & & $p=0.414$ * & $p=0.008$ * \\
\hline $0-8$ & 464 & $24.6(22.5-26.8)$ & 1.00 & 1.00 \\
\hline $9-11$ & 457 & $25.2(19.9-31.2)$ & $1.01(0.81-1.26)$ & $0.81(0.63-1.54)$ \\
\hline$\geq 12$ & 386 & $26.4(22.0-31.4)$ & $1.08(0.90-1.29)$ & $0.66(0.51-0.87)$ \\
\hline Per capita monthly income (R\$) & & & $p=0.033$ * & $p=0.982 *$ \\
\hline 1st tercile $(\leq 240.00)$ & 401 & $21.7(18.3-25.5)$ & 1.00 & 1.00 \\
\hline $2^{\text {nd }}$ tercile (> 240.00 and $\leq 500.00$ ) & 430 & $24.4(20.0-29.5)$ & $1.11(0.88-1.41)$ & $1.00(0.66-1.51)$ \\
\hline $3^{\text {rd }}$ tercile $(>500.00)$ & 316 & $29.1(26.1-32.4)$ & $1.34(1.08-1.66)$ & $1.05(0.55-1.98)$ \\
\hline Schoolchild's age group (years) & & & $p=0.584$ & $p=0.247$ \\
\hline $7-10$ & 604 & $26.0(23.1-29.1)$ & 1.00 & 1.00 \\
\hline $11-14$ & 755 & $24.9(21.6-28.5)$ & $0.96(0.81-1.13)$ & $1.36(0.80-2.30)$ \\
\hline \multicolumn{5}{|l|}{ Level 2} \\
\hline School type & & & $p=0.010$ & $p=0.905$ \\
\hline Public & 1,022 & $24.0(20.8-27.5)$ & 1.00 & 1.00 \\
\hline Private & 337 & $29.7(27.7-31.7)$ & $1.23(1.06-1.44)$ & $1.03(0.67-1.58)$ \\
\hline Parents' nutritional state & & & $p<0.001$ & $p=0.002$ \\
\hline Neither overweight/obese & 346 & $18.5(14.9-22.7)$ & 1.00 & 1.00 \\
\hline Father overweight/obese & 401 & $27.4(23.8-31.4)$ & $1.48(1.18-1.86)$ & $1.53(1.13-2.07)$ \\
\hline Mother overweight/obese & 149 & $22.8(18.0-28.4)$ & $1.23(0.91-1.68)$ & $1.41(0.99-2.01)$ \\
\hline Both overweight/obese & 225 & $34.2(28.6-40.3)$ & $1.83(1.39-2.42)$ & $1.83(1.27-2.65)$ \\
\hline \multicolumn{5}{|l|}{ Level 3} \\
\hline Consumption of protective foods ** & & & $p=0.139$ & $p=0.562$ \\
\hline Appropriate ( $\geq 5$ times/day) & 163 & $22.1(17.0-28.1)$ & 1.00 & 1.00 \\
\hline Inappropriate ( $<5$ times/day) & 1,196 & $25.8(23.5-28.3)$ & $1.19(0.94-1.51)$ & $1.09(0.80-1.49)$ \\
\hline 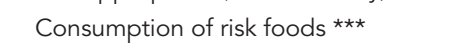 & & & $p=0.161$ & $p=0.319$ \\
\hline Appropriate (<2 times/day) & 259 & $29.3(23.4-36.0)$ & 1.00 & 1.00 \\
\hline Inappropriate ( $\geq 2$ times/day) & 1,100 & $24.4(21.6-27.6)$ & $0.83(0.63-1.08)$ & $0.84(0.59-1.19)$ \\
\hline Skipping breakfast & & & $p=0.923$ & $p=0.382$ \\
\hline No & 1,293 & $25.3(23.1-27.8)$ & 1.00 & 1.00 \\
\hline Yes & 66 & $25.7(16.2-38.4)$ & $1.02(0.67-1.54)$ & $0.77(0.42-1.40)$ \\
\hline Number of meals/day & & & $p<0.001$ & $p=0.051$ \\
\hline Up to 3 & 298 & $30.5(26.8-34.6)$ & 1.00 & 1.00 \\
\hline 4 & 360 & $28.9(25.0-33.1)$ & $0.95(0.81-1.11)$ & $0.84(0.66-1.06)$ \\
\hline 5 & 454 & $22.5(19.0-26.4)$ & $0.74(0.62-0.87)$ & $0.73(0.56-0.94)$ \\
\hline 6 & 245 & $18.8(14.8-23.6)$ & $0.61(0.48-0.79)$ & $0.78(0.58-1.07)$ \\
\hline
\end{tabular}

* Trend p-value;

** Fruit, natural juices, leaf vegetables, other vegetables, vegetable soup;

*** Chocolate products, soft drinks, artificial juices, sweets, packaged snacks, French fries and fast-food. 


\section{Table 4}

Adjusted analysis * for association between overweight/obesity in schoolchildren and the variables included in the final model, among males and females. Florianópolis, Santa Catarina State, Brazil, 2007.

\begin{tabular}{|c|c|c|}
\hline Variables & Adjusted PR (95\%Cl) & p-value \\
\hline \multicolumn{3}{|l|}{ Male ** } \\
\hline Father's age group (years) & & $p=0.202$ \\
\hline $20-39$ & 1.00 & \\
\hline$\geq 40$ & $1.25(0.88-1.78)$ & \\
\hline Mother's age group (years) & & $p=0.004$ \\
\hline $20-39$ & 1.00 & \\
\hline$\geq 40$ & $1.40(1.12-1.74)$ & \\
\hline Father's schooling (years) & & $p=0.009$ \\
\hline $0-8$ & 1.00 & \\
\hline $9-11$ & $1.09(0.83-1.42)$ & \\
\hline$\geq 12$ & $1.51(1.17-1.95)$ & \\
\hline Mother's schooling (years) & & $p=0.008$ \\
\hline $0-8$ & 1.00 & \\
\hline $9-11$ & $0.81(0.63-1.54)$ & \\
\hline$\geq 12$ & $0.66(0.51-0.87)$ & \\
\hline Parents' nutritional state & & $p=0.002$ \\
\hline Neither overweight/obese & 1.00 & \\
\hline Father overweight/obese & $1.53(1.13-2.07)$ & \\
\hline Mother overweight/obese & $1.41(0.99-2.01)$ & \\
\hline Both overweight/obese & $1.83(1.27-2.65)$ & \\
\hline Number of meals/day & & $p=0.051$ \\
\hline Up to 3 & 1.00 & \\
\hline 4 & $0.84(0.66-1.06)$ & \\
\hline 5 & $0.73(0.56-0.94)$ & \\
\hline 6 & $0.78(0.58-1.07)$ & \\
\hline \multicolumn{3}{|l|}{ Female ${ }^{\star * \star}$} \\
\hline Schoolchild's age group (years) & & $p<0.001$ \\
\hline $7-10$ & 1.00 & \\
\hline $11-14$ & $0.37(0.28-0.48)$ & \\
\hline Parents' nutritional state & & $p<0.001$ \\
\hline Neither overweight/obese & 1.00 & \\
\hline Father overweight/obese & $1.18(0.78-1.78)$ & \\
\hline Mother overweight/obese & $1.78(1.29-2.47)$ & \\
\hline Both overweight/obese & $2.53(1.82-3.51)$ & \\
\hline Protective foods/day ** & & $p=0.185$ \\
\hline Appropriate ( $\geq 5$ times) & 1.00 & \\
\hline Inappropriate $(<5$ times) & $0.81(0.59-1.11)$ & \\
\hline Risk foods/day & & $p=0.029$ \\
\hline Appropriate ( $<2$ times) & 1.00 & \\
\hline Inappropriate ( $\geq 2$ times) & $0.67(0.46-0.96)$ & \\
\hline
\end{tabular}

* The variables at each level were adjusted for each other and for those at the next highest level with $p \leq 0.20$;

** At the first level the variables were adjusted for sexual maturity, father's and mother's age groups and father's and mother's schooling; at the second level, for parents' nutritional state and; at the third level, for number of meals daily;

*** At the first level the variables were adjusted for sexual maturity and schoolchild's age group; at the second level, for parents' nutritional state; and, at the third level, for consumption of protective and risk foods. 
Prevalence and crude and adjusted prevalence ratios for overweight/obesity in female schoolchildren, by independent variables. Florianópolis, Santa Catarina State, Brazil, 2007.

\begin{tabular}{|c|c|c|c|c|}
\hline Variables & $\mathrm{n}$ & $\begin{array}{c}\text { Overweight/Obesity } \\
\%(95 \% \mathrm{Cl})\end{array}$ & Crude PR $(95 \% \mathrm{Cl})$ & Adjusted PR $(95 \% \mathrm{Cl})$ \\
\hline \multicolumn{5}{|l|}{ Level 1} \\
\hline Father's age group (years) & & & $p=0.436$ & $p=0.595$ \\
\hline $20-39$ & 601 & $20.1(17.1-23.5)$ & 1.00 & 1.00 \\
\hline$\geq 40$ & 730 & $18.5(15.4-22.0)$ & $0.93(0.77-1.13)$ & $1.05(0.86-1.29)$ \\
\hline Mother's age group (years) & & & $p=0.596$ & $p=0.833$ \\
\hline $20-39$ & 893 & $19.3(16.3-22.6)$ & 1.00 & 1.00 \\
\hline$\geq 40$ & 552 & $17.9(14.7-21.6)$ & $0.95(0.77-1.17)$ & $1.03(0.76-1.40)$ \\
\hline Father's schooling (years) & & & $p=0.059$ * & $p=0.326$ \\
\hline $0-8$ & 473 & $21.6(17.7-26.0)$ & 1.00 & 1.00 \\
\hline $9-11$ & 411 & $20.9(17.5-24.8)$ & $0.98(0.79-1.22)$ & $1.06(0.86-1.29)$ \\
\hline$\geq 12$ & 426 & $15.7(11.9-20.5)$ & $0.74(0.54-1.01)$ & $0.82(0.59-1.14)$ \\
\hline Mother's schooling (years) & & & $p=0.109$ & $p=0.454$ \\
\hline $0-8$ & 498 & $19.5(16.1-23.3)$ & 1.00 & 1.00 \\
\hline $9-11$ & 487 & $21.1(18.5-24.1)$ & $1.10(0.90-1.35)$ & $1.06(0.76-1.48)$ \\
\hline$\geq 12$ & 439 & $15.3(11.2-20.4)$ & $0.78(0.58-1.05)$ & $0.80(0.44-1.44)$ \\
\hline Per capita monthly income (R\$) & & & $p=0.604$ & $p=0.657$ \\
\hline 1st tercile $(\leq 240.00)$ & 432 & $21.8(16.6-27.9)$ & 1.00 & 1.00 \\
\hline $2^{\text {nd }}$ tercile (> 240.00 and $\left.\leq 500.00\right)$ & 463 & $16.6(14.1-19.5)$ & $0.76(0.59-1.04)$ & $0.85(0.60-1.22)$ \\
\hline 3 rd tercile $(>500.00)$ & 373 & $19.8(14.9-25.9)$ & $0.91(0.62-1.35)$ & $1.12(0.74-1.68)$ \\
\hline Schoolchild's age group (years) & & & $p=0.010$ & $p<0.001$ \\
\hline $7-10$ & 627 & $22.8(19.9-25.9)$ & 1.00 & 1.00 \\
\hline $11-14$ & 840 & $15.7(12.0-20.2)$ & $0.70(0.53-0.92)$ & $0.37(0.28-0.48)$ \\
\hline \multicolumn{5}{|l|}{ Level 2} \\
\hline School type & & & $p=0.132$ & $p=0.919$ \\
\hline Public & 1,109 & $19.8(17.0-23.0)$ & 1.00 & 1.00 \\
\hline Private & 358 & $15.3(11.4-20.4)$ & $0.78(0.57-1.08)$ & $0.98(0.72-1.34)$ \\
\hline Parents' nutritional state & & & $p<0.001$ * & $p<0.001$ * \\
\hline Neither overweight/obese & 395 & $11.9(8.7-16.0)$ & 1.00 & 1.00 \\
\hline Father overweight/obese & 408 & $15.4(12.0-19.6)$ & $1.29(0.89-1.89)$ & $1.18(0.78-1.78)$ \\
\hline Mother overweight/obese & 159 & $23.9(17.5-31.7)$ & $2.01(1.45-2.79)$ & $1.78(1.29-2.47)$ \\
\hline Both overweight/obese & 252 & $34.9(30.1-40.1)$ & $2.96(2.16-4.05)$ & $2.53(1.82-3.51)$ \\
\hline \multicolumn{5}{|l|}{ Level 3} \\
\hline Protective foods/day ** & & & $p=0.505$ & $p=0.185$ \\
\hline Appropriate ( $\geq 5$ times) & 187 & $20.3(15.0-26.9)$ & 1.00 & 1.00 \\
\hline Inappropriate (< 5 times) & 1,280 & $18.5(15.7-21.6)$ & $0.90(0.64-1.25)$ & $0.81(0.59-1.11)$ \\
\hline 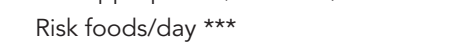 & & & $p=0.001$ & $p=0.029$ \\
\hline Appropriate (<2 times) & 295 & $26.4(22.1-31.3)$ & 1.00 & 1.00 \\
\hline Inappropriate ( $\geq 2$ times) & 1,172 & $16.8(13.9-20.1)$ & $0.64(0.50-0.83)$ & $0.67(0.46-0.96)$ \\
\hline Skipping breakfast & & & $p=0.139$ & $p=0.352$ \\
\hline No & 1,373 & $18.2(15.4-21.4)$ & 1.00 & 1.00 \\
\hline Yes & 94 & $26.6(17.6-38.1)$ & $1.45(0.88-2.39)$ & $1.28(0.75-2.18)$ \\
\hline Number of meals/day & & & $p=0.015$ & $p=0.894$ \\
\hline Up to 3 & 352 & $21.9(18.1-26.1)$ & 1.00 & 1.00 \\
\hline 4 & 430 & $20.3(16.7-24.3)$ & $0.92(0.72-1.18)$ & $1.19(0.85-1.67)$ \\
\hline 5 & 450 & $17.1(13.7-21.1)$ & $0.78(0.59-1.04)$ & $1.02(0.67-1.55)$ \\
\hline 6 & 237 & $15.2(11.2-20.3)$ & $0.69(0.49-0.98)$ & $1.10(0.76-1.59)$ \\
\hline
\end{tabular}

* Trend p-value;

** Fruit, natural juices, leaf vegetables, other vegetables, vegetable soup;

*** Chocolate products, soft drinks, artificial juices, sweets, packaged snacks, French fries and fast-food. 
etary variables, consumption of health-risk foods and the number of meals daily showed a protective effect on the outcome.

In the unadjusted analyses for the girls, at the first level, only the schoolgirls' age continued associated with the outcome. At the second level, the parents' nutritional status was strongly associated with the outcome and, at the third level of analysis, only consumption of health-risk foods continued to display the protective effect after adjustment (Table 4 ).

\section{Discussion}

The study indicated a prevalence of overweight/ obesity of $21.9 \%$ in schoolchildren $7-14$ years old in the city of Florianópolis, in 2007, according to IOTF criteria ${ }^{8}$. This finding reveals a high prevalence, corroborating studies of schoolchildren in various regions of Brazil 31,32. Comparing these findings with international studies using the same diagnostic criteria, the prevalence observed is lower than in schoolchildren in Canada 2 and the United States 5, but higher than in Spanish schoolchildren 2.

Analyzing by sex, the outcome was more prevalent among boys than among girls, and the difference statistically significant, as in a study of adolescents 11-17 years old $(n=1,179)$ in Presidente Prudente, São Paulo State 33 . However, a study of schoolchildren of both sexes 7-14 years old $(\mathrm{n}=1,257$ ) in the Cotinguiba micro-region, in Sergipe State ${ }^{34}$, showed a higher prevalence among girls. There are also studies showing no significant differences between the sexes 7,10,31.

A higher prevalence of overweight/obesity among the fathers than the mothers can be explained by the fact that most of the men were 40 years old or more, while most of the women were from 20 to 39 years old, and the trend is for the prevalence of overweight/obesity to increase with advancing age. Results of Brazil's 2008-2009 POF corroborate this higher prevalence of overweight/obesity among men than women in Brazil, as well as increasing prevalence with advancing age, in both sexes 6 .

Various different variables showed an association with overweight/obesity in the schoolchildren, supporting studies that have investigated and identified its multifactorial origin 10,11,35. In addition, the results differed between boys and girls, indicating sex-specific features.

By age group, the female schoolchildren showed an inverse association with overweight/ obesity, as also found in studies of schoolchildren from 10 to 14 years old $(n=1,405)$ of both sexes in the city of Recife, Pernambuco State 36, and of schoolchildren 6 to 11 years old of both sexes ( $n=20,084$ ) in Pelotas, Rio Grande do Sul State 17 . In this present study, however, among the male schoolchildren, age group showed no association with overweight/obesity.

In addition, the adjusted analyses showed that, among the boys, there was an inverse association between mother's schooling and overweight/obesity in the schoolchildren, as in the findings by Giugliano \& Carneiro 10. The father's schooling, meanwhile, was directly associated with overweight/obesity in the boys, corroborating Bharati et al. 15. In the girls, no associations were observed between overweight/obesity and parents' schooling.

Monthly per capita income showed no association with the outcome in this study after adjustment, although inverse associations have previously been found between family income and overweight/obesity in children and adolescents 37 .

Of the dietary variables, the only association found in the girls was the protective effect of consumption of health-risk foods on overweight/obesity. This finding is similar to that of Hanley et al. 38 among 242 Canadian schoolchildren from 10 to 19 years old, although it disagrees with most studies of the association between the quality of food consumed and overweight/obesity in schoolchildren $12,39,40$. That consumption of health-risk foods displays a protective effect on overweight/obesity can be explained by the cross-sectional study design, which is prone to reverse causality, which prevents a clear causeand-effect relationship being established between the variable analyzed and overweight/ obesity in the schoolchildren. Another aspect to be considered is the use of the QUADA, which although developed for the age range under study, examines only one day's food intake, in addition to not allowing the exact quantities of food consumed to be measured. On the other hand, the instrument does make it possible to identify the nutritional quality of the foods consumed by the schoolchildren, and whether or not those considered a health risk are consumed more than once a day, which can then inform suggestions for changes and improvements in eating habits.

Among the boys, the number of meals daily showed a protective effect on overweight/obesity, corroborating Dutra et al. 13, who studied 810 schoolchildren 10 to 19 years old. Although the present study found no association between skipping breakfast and overweight/obesity in the schoolchildren, some studies have shown such an association 12,13. One explanation offered by Nicklas et al. 12 is that the habit of eating breakfast tends to reduce dietary fat intake 
by favoring greater intake of grains, fruits and dairy products in the meal. In this way it reduces consumption of fast-food snacks, which are generally high energy value and rich in fats, sugars and salt. A study of adolescents in South Korea showed obesity among the girls who ate meals most irregularly, and who consequently ate more fast-food snacks 40 . In this respect, skipping meals, including breakfast, favors unhealthy and inappropriate choices at later meals at irregular hours, while more meals per day at regular times is regarded as contributing to control of body weight.

The variable most strongly associated with overweight/obesity in schoolchildren, both boys and girls, was their parents' nutritional status. The hazard proved highest for boys both of whose parents were overweight/obese, followed by boys whose father alone was overweight/obese. Among the girls, has it was high for those both of whose parents were overweight/obese and, unlike the boys, this was followed by the girls whose mother alone was overweight/obese. Schoolchildren both of whose parents were overweight/ obese displayed more than $100 \%$ higher hazard than the children of parents without overweight/ obesity. Other Brazilian studies showing the association between fathers' and mothers' nutritional status and those of their sons and daughters can be found in the literature, such as Guimarães et al. 11 , of schoolchildren of both sexes from 6 to 11 years old in Cuiabá; Giugliano \& Carneiro 10, of school children 6 to 10 years old in Brasília; and Suñé et al. 18 of schoolchildren from 11 to 13 years old in Capão da Canoa.

In this present study, the fathers' nutritional status was observed to associate more with the sons' nutritional status, while the mothers' associated more with the daughters'. This finding was noted previously by Kosti et al. 41 and, of the studies that have investigated this association, another found a relationship only between the girls' nutritional status and their mothers', but not with their fathers' 42 . These findings may relate to the fact that parents serve as an example to their children, influencing the formation of their living habits, including dietary habits, which signals the importance of the parents' participating in activities to promote health and prevent overweight/obesity in schoolchildren.

As regards the limitations and potential of this present study, it is important to stress that, although there is no established definition of quality for anthropometric measurements selfreported by the parents, such measurements proved satisfactorily reliable in a previous study in Brazil 43. In addition, the methodological rigor of the research endowed the findings with a high degree of reliability, given that the team of examiners was trained previously 27 . The study's limitations include its use of a QUADA to analyze food intake, because a validation study of this instrument, although finding sensitivity values in excess of $60 \%$ for most of the food groups considered (9/12), found low sensitivity as regards confectionary $(43.4 \%)$ and soft drinks (36\%) 28 consumed the previous day. Accordingly, it is suggested that future studies of the association between schoolchildren's dietary habits and nutritional status use a different methodology to analyze consumption, one that considers not only what the schoolchildren report, but also the information supplied by their parents about what foods their children eat.

Because the study was of the cross-sectional type it is subject to limitations relating to reverse causality, particularly as it addresses behavioral variables. It is suggested that studies with longitudinal design be used to investigate the relationship among the possible factors associated with overweight/obesity in schoolchildren in greater depth, so as to inform the development of strategies that can prevent the advance of this epidemic. 


\section{Resumo}

O objetivo deste estudo foi analisar a associação entre estado nutricional dos pais, variáveis sociodemográficas, dietéticas e o sobrepeso/obesidade em escolares de 7-14 anos de Florianópolis, Santa Catarina, Brasil. Estudo transversal com 2.826 escolares, classificados com base nas curvas de indice de massa corporal para idade e sexo segundo a International Obesity Task Force. Para as análises utilizou-se a Regressão de Poisson. No modelo final, mostraram associação direta ao sobrepeso/obesidade em meninos: escolaridade do pai, idade da mãe e estado nutricional dos pais; e inversa: escolaridade da mãe e número de refeições diárias. Entre as meninas houve associação direta com estado nutricional dos pais, e inversa com idade do escolar e consumo de alimentos de risco. As variáveis associadas ao sobrepeso/obesidade diferiram entre os sexos, com exceção do estado nutricional dos pais. Filhos e filhas de ambos os pais com sobrepeso/obesidade têm risco cerca de, respectivamente, $80 \%$ e $150 \%$ maior de apresentar o mesmo diagnóstico, indicando a necessidade de intervenções também no ambiente familiar.

Sobrepeso; Obesidade; Relações Pai-Filho

\section{Contributors}

C. O. Bernardo was responsible for data collection, analysis and interpretation, drafting the article, and approving the final version for publication. F. A. G. Vasconcelos was responsible for formulating and coordinating the project, for substantial critical review of the intellectual content, and final approval of the version for publication.

\section{Acknowledgments}

To Prof. David Alejandro González-Chica for assistance in the statistical analysis and discussion of the findings. To CNPq for financing the study (process no. 402322/2005-3 - Call for Projects MCT/CNPq/MSSCTIE-DECIT/SAS-DAB 51/2005).

\section{References}

1. World Health Organization. Obesity: preventing and managing the global epidemic. Geneva: World Health Organization; 2000. (WHO Technical Report Series, 894).

2. Lobstein T, Baur L, Uauy R; IASO International Obesity Task Force. Obesity in children and young people: a crisis in public health. Obes Rev 2004; 5 Suppl 1:4-104.

3. Guo SS, Chumlea WC. Tracking of body mass index in children in relation to overweight in adulthood. Am J Clin Nutr 1999; 70:145S-8S.

4. Herman KM, Craig CL, Gauvin L, Katzmarzyk PT. Tracking of obesity and physical activity from childhood to adulthood: The Physical Activity Longitudinal Study. Int J Pediatr Obes 2008; 15:1-8.
5. Wang Y, Monteiro C, Popkin BM. Trends of obesity and underweight in older children and adolescents in the United States, Brazil, China, and Russia. Am J Clin Nutr 2002; 75:971-7.

6. Instituto Brasileiro de Geografia e Estatística. Pesquisa de Orçamentos Familiares 2008-2009. Antropometria e análise do estado nutricional de crianças, adolescentes e adultos no Brasil. Rio de Janeiro: Instituto Brasileiro de Geografia e Estatística; 2010.

7. Ricardo GD, Caldeira GV, Corso ACT. Prevalência de sobrepeso e obesidade e indicadores de adiposidade central em escolares de Santa Catarina, Brasil. Rev Bras Epidemiol 2009; 12:424-35. 
8. Cole TJ, Bellizzi MC, Flegal KM, Dietz WH. Establishing a standard definition for child overweight and obesity worldwide: international survey. BMJ 2000; 320:1240-3.

9. Assis MAA, Rolland-Cachera MF, Grosseman S, Vasconcelos FAG, Luna MEP, Calvo MCM. Obesity, overweight and thinness in schoolchildren of the city of Florianópolis, Southern Brazil. Eur J Clin Nutr 2005; 59:1015-21.

10. Giugliano R, Carneiro EC. Fatores associados à obesidade em escolares. J Pediatr (Rio J.) 2004; 80:17-22.

11. Guimarães LV, Barros MBA, Martins MSAS, Duarte EC. Fatores associados ao sobrepeso em escolares. Rev Nutr 2006; 19:5-17.

12. Nicklas TA, Baranowski T, Cullen KW, Berenson G. Eating patterns, dietary quality and obesity. J Am Coll Nutr 2001; 6:599-608.

13. Dutra CL, Araújo CL, Bertoldi AD. Prevalência de sobrepeso em adolescentes: um estudo de base populacional em uma cidade no Sul do Brasil. Cad Saúde Pública 2006; 22:151-62.

14. Barbiero SM, Pellanda LC, Cesa CC, Campagnolo P, Beltrami F, Abrantes CC. Overweight, obesity and other risk factors for IHD in Brazilian schoolchildren. Public Health Nutr 2009; 12:710-5.

15. Bharati DR, Deshmukh PR, Garg BS. Correlates of overweight and obesity among school going children of Wardha city, Central India. Indian J Med Res 2008; 127:539-43.

16. Neutzling MB, Taddei JA, Rodrigues EM, Sigulem DM. Overweight and obesity in Brazilian adolescents. Int J Obes Relat Metab Disord 2000; 24: 869-74.

17. Vieira MFA, Araujo CL, Hallal P. Estado nutricional de escolares de 1ạ a 4ạ séries do Ensino Fundamental das escolas urbanas da cidade de Pelotas, Rio Grande do Sul, Brasil. Cad Saúde Pública 2008; 24:1667-74.

18. Suñé FR, Dias-da-Costa JS, Olinto MTA, Pattussi MP. Prevalência e fatores associados para sobrepeso e obesidade em escolares de uma cidade no Sul do Brasil. Cad Saúde Pública 2007; 23:1361-71.

19. Malina RM, Bouchard C. Growth, maturation, and physical activity. Champaign: Human Kinetics Books; 1991.

20. Himes JH, Obarzanek E, Baranowski T, Wilson DM, Rochon J, Mcclanahan BS. Early sexual maturation, body composition, and obesity in AfricanAmerican girls. Obes Res 2004; 12 Suppl:64S-72.

21. Adami F, Vasconcelos FAG. Obesidade e maturação sexual precoce em escolares de Florianópolis - SC. Rev Bras Epidemiol 2008; 11:549-60.

22. United Nations Development Programme. Atlas do Desenvolvimento Humano no Brasil. Brasília: Programa das Nações Unidas para o Desenvolvimento; 2003.

23. Abrantes MM, Lamounier JA, Colosimo EA. Comparison of body mass index values proposed by Cole et al. (2000) and Must et al. (1991) for identifying children with weght-for-height index recommended by the World Health Organization. Public Health Nutr 2003; 6:307-11.
24. Salles RK, Kazapi IAM, Di Pietro P. Ocorrência de obesidade em adolescentes da rede de ensino do município de Florianópolis. In: Oliveira JED, Lamounier JA, Assis AMO, Berezovsky MW, Portella Jr. AO, organizadores. Anais do simpósio: obesidade e anemia carencial na adolescência. São Paulo: Instituto Danone; 2000. p. 21.

25. World Health Organization. Physical status: the use and interpretation of anthropometry. Geneva: World Health Organization; 1995. (Technical Report Series, 854).

26. Lohman TG, Roche AF, Martorell R. Anthropometric standardization reference manual. Illinois: $\mathrm{Hu}-$ man Kinetics Books, 1988.

27. Frainer DE, Adami F, Vasconcelos FAG, Assis MAA, Calvo MC, Kerpel R. Standardization and reliability of anthropometric measurements for population surveys. Arch Latinoam Nutr 2007; 57:335-42.

28. Assis MAA, Benedet J, Kerpel R, Vasconcelos FAG, Di Pietro PF, Kupek E. Validação da terceira versão do Questionário Alimentar do Dia Anterior (QUADA-3) para escolares de 6 a 11 Anos. Cad Saúde Pública 2009; 25:1816-26.

29. Coordenação Geral da Política de Alimentação e Nutrição, Departamento de Atenção Básica, Secretaria de Atenção à Saúde, Ministério da Saúde. Guia alimentar para a população brasileira: promovendo a alimentação saudável. Brasília: Ministério da Saúde; 2006.

30. Barros AJ, Hirakata VN. Alternatives for logistic regression in cross-sectional studies: an empirical comparison of models that directly estimate the prevalence ratio. BMC Med Res Methodol 2003; 3:21.

31. Pelegrini A, Silva DAS, Petroski EL, Gaya ACA. Sobrepeso e obesidade em escolares brasileiros de sete a nove anos: dados do projeto Esporte Brasil. Rev Paul Pediatr 2010; 28:290-95.

32. Mello ADM, Marcon SS, Hulsmeyer APCR, Cattai GBP, Ayres CSLS, Santana RG. Prevalência de sobrepeso e obesidade em crianças de seis a dez anos de escolas municipais de área urbana. Rev Paul Pediatr 2010; 28:48-54.

33. Fernandes RA, Codogno JS, Cardoso JR, Ronque ERV, Freitas Junior JIF, Oliveira AR. Fatores associados ao excesso de peso entre adolescentes de diferentes redes de ensino do município de Presidente Prudente, São Paulo. Rev Bras Saúde Mater Infant 2009; 9:443-9.

34. Petroski EL, Silva RJS, Pelegrini A. Crescimento físico e estado nutricional de crianças e adolescentes da região de Cotinguiba, Sergipe. Rev Paul Pediatr 2008; 26:206-11.

35. Enes CC, Slater B. Obesidade na adolescência e seus principais fatores determinantes. Rev Bras Epidemiol 2010; 13:163-71.

36. Pinto ICS, Arruda IKG, Diniz AS, Cavalcanti AMTS. Prevalência de excesso de peso e obesidade abdominal, segundo parâmetros antropométricos, e associação com maturação sexual em adolescentes escolares. Cad Saúde Pública 2010; 26:1727-37. 
37. Forrest KY, Leeds MJ. Prevalence and associated factors of overweight among Mexican-American adolescents. J Am Diet Assoc 2007; 107:1797-800.

38. Hanley JG, Harris SB, Gittelsohn J, Wolever TMS, Saksvig B, Zinman B. Overweight among children and adolescents in a Native Canadian community: prevalence and associated factors. Am J Clin Nutr 2000; 71:693-700.

39. Amin TT, Al-Sultan AI, Ali A. Overweight and obesity and their relation to dietary habits and sociodemographic characteristics among male primary school children in Al-Hassa, Kingdom of Saudi Arabia. Eur J Nutr 2008; 47:310-8.

40. Yoon J, Lee N. Dietary patterns of obese high school girls: snack consumption and energy intake. Nutr Res Pract 2010; 4:433-7.
41. Kosti RI, Panagiotakos DB, Tountas Y, Mihas CC, Alevizos A, Mariolis T, et al. Parental Body Mass Index in association with the prevalence of overweight/obesity among adolescents in Greece; dietary and lifestyle habits in the context of the family environment: The Vironas study. Appetite 2008; 51:218-22.

42. Castro-Burbano JC, Fornasini M, Acosta M. Prevalencia y factores de riesgo de sobrepeso em colegialas de 12 a 19 años en una región semiurbana del Ecuador. Rev Panam Salud Pública 2003; 13:277-84

43. Fonseca MJM, Faerstein E, Chor D, Lopes CS. Validade de peso e estatura informados e índice de massa corporal: estudo pró-saúde. Rev Saúde Pública 2004; 38:392-8.

Submitted on 17/Mar/2011

Final version resubmitted on 10/Aug/2011

Approved on 22/Aug/2011 